\title{
Protein Data Bank
}

National Cancer Institute

\section{Source}

National Cancer Institute. Protein Data Bank. NCI Thesaurus. Code C49039.

A worldwide repository for the processing and distribution of 3-D biological

macromolecular structure data. 